\title{
Progress of Pruritus Research in Atopic Dermatitis
}

\author{
Chang-Hoon LEE* \\ Department of Life Science, Dongguk University, Seoul 100-715, Republic of Korea
}

(Received July 16, 2010; Revised July16, 2010; Accepted July 21, 2010)

\begin{abstract}
Atopic dermatitis is a common skin disease affecting up to $10 \%$ of children and approximately $2 \%$ of adults. Atopic dermatitis exhibits four major symptoms, including intense itching, dry skin, redness and exudation. The "itch-scratch-itch" cycle is one of the major features in atopic dermatitis. The pathophysiology and neurobiology of pruritus is unclear. Currently there are no single and universally effective pharmacological antipruritic drugs for treatment of atopic dermatitis. Thus, controlling of itch is a very important unmet need in patients suffering from atopic dermatitis. This article will update progress during the past 10 years of research in the field of pruritus of atopic dermatitis, focusing on aspects of pruritogens (including inflammatory lipids, histamine, serotonin, proteinases, proteinase-activating receptors, neurotransmitters, neuropeptides, and opioid peptides), antipruritic therapies, and emerging new targets. Based on recent progress, researchers expect to identify exciting possibilities for improved treatments and to develop new antipruritic drugs acting through novel targets, such as histamine $\mathrm{H} 4$ receptor, gastrin-releasing peptide receptor, MrgprA3, thromboxane A2 receptor and the putative SPC receptor.
\end{abstract}

Keywords: Pruritus, Atopic dermatitis, Pruritogen, Antipruritic therapy, New target

Atopic dermatitis (AD) is a common skin disease that affects up to $10 \%$ of children and approximately $2 \%$ of adults in the general population (Leung and Soter, 2001). The socio-economic losses resulting from the disease are high; the cost of illness to the third-party payer for $A D$ ranges from US $\$ 0.9$ billion to US $\$ 3.8$ billion (Ellis et al., 2002). The quality-of-life is remarkably lowered by AD. The genetic background, in combination with several environmental factors, results in this chronic remittent skin disease. $A D$ exhibits four major symptoms including intense itching (pruritus), dry skin (xerosis), redness (erythema) and exudation. The "itch-scratch-itch" cycle is a common feature of AD. Scratching can cause bleeding, secondary infection (bacterial, fungal and/or viral) and thickening of the skin (lichenification) (Lewis-Jones, 2005). Itching is the predominant symptom of $A D$ and is also an important diagnostic feature of systemic disease (Malekzad et al., 2009).

The pathophysiology and neurobiology of pruritus are unclear. Therefore it is not surprising that anti-pruritus ther-

${ }^{*}$ Corresponding author

Tel: +82-2-2260-8905 Fax: +82-2-2260-8769

E-mail: uatheone@gmail.com apy is not well established and the choice of therapeutic agents is limited. However, recent progress over the past 10 years has provided insights into the neurophysiology of pruritus and is opening up exciting possibilities for development of new antipruritic drugs (Yosipovitch and Papoiu, 2008; Liu et al., 2009; Sun et al., 2009).

Itch can be regarded as a cutaneous sensory perception, which requests excitation of specialized itch receptors in the skin. Increased amounts of neurofilament-, protein gene product (PGP) 9.5-, calcitonin gene-related peptide (CGRP)-, and substance P (SP)-positive nerve fibres have been observed in the papillary dermis, at the dermoepidermal junction, in the epidermis and around sweat glands of lesional atopic skin (Stander and Steinhoff, 2002). These observations clearly demonstrated that the density of cutaneous nerve fibers is altered in atopic skin lesions. Neurite density and expression levels of growth factors and gelatinase were remarkably increased in the epidermis of an atopic mouse model (Conv-NC/Nga mice), compared with those of SPF-NC/Nga mice (Tominaga et al., 2007). 


\section{MEDIATORS OF ITCH IN ATOPIC SKIN}

Pruritogens are the endogenous compounds which mediate itch-scratch responses. Identification of the pruritogens and elucidation of their mechanisms of action are very im- portant goals for controlling the pruritus of AD. Several mediators causing pruritus are described in review papers (Stander and Steinhoff, 2002; Yosipovitch and Papoiu, 2008). In this paper, I briefly summarize and update the well-known pruritogens and recent progress in inves-

Table I. Nociception in atopic skin: mediators and their mechanisms inducing pruritus in AD (for references see text)

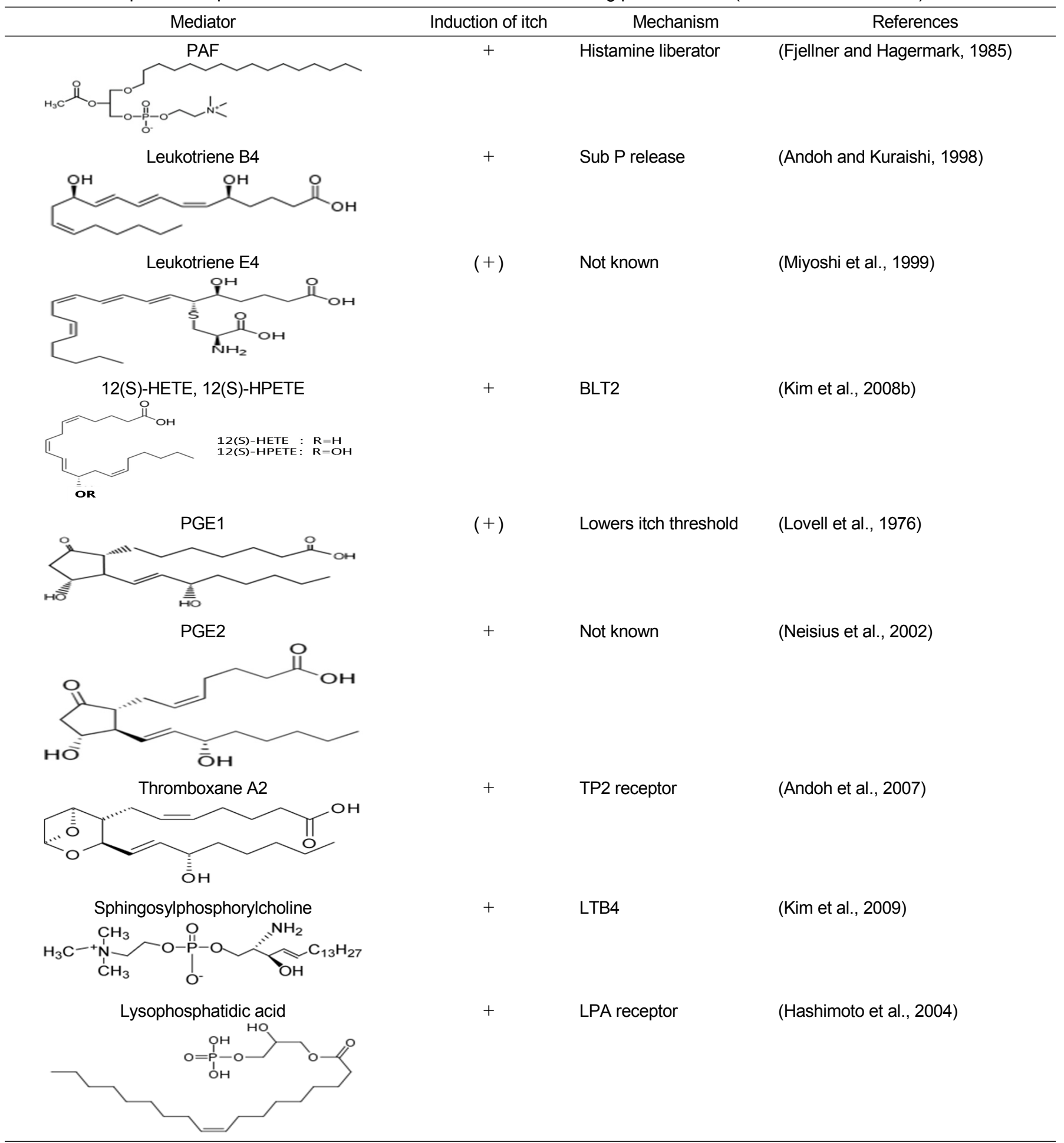


tigation of itch mediators.

\section{Inflammatory lipids (Table I)}

Platelet activating factor (PAF) is a lipid mediator with a potent pro-inflammatory activity and is released by several inflammatory cells, including eosinophils (Czarnetzki and Csato, 1989). Consequently, a wheal and flare reaction, as well as pruritus, resulted after intradermal injection of PAF, suggesting release of histamine (Fjellner and Hagermark, 1985) (Table I). Several PAF antagonists have been developed, and preliminary results of a double blind study using a topically applied synthetic PAF antagonist showed a statistically significant reduction of pruritus in patients with $A D$ during the first 2 weeks of therapy (Abeck et al., 1997).

Leukotrienes are products of several lipoxygenases. Currently, the role of leukotrienes in the pathogenesis of pruritus is speculative, although there is increasing evidence of their relevance in elicitation of itch (Table I). Andoh et al. (Andoh and Kuraishi, 1998) demonstrated that intradermally injected leukotriene $\mathrm{B}_{4}\left(\mathrm{LTB}_{4}\right)$ was able to provoke scratching in mice. $\mathrm{LTB}_{4}$ increased intracellular $\mathrm{Ca}^{2+}$ concentration in cultured DRG neurons, which was inhibited by an $\mathrm{LTB}_{4}$ receptor antagonist. The actions of leukotrienes are mediated by leukotriene receptors. High affinity leukotriene $B_{4}$ receptor (BLT1) and low affinity leukotriene $B_{4}$ receptor (BLT2) are leukotriene receptors. It is reported that BLT1, but not BLT2 receptor mRNA is expressed in the dorsal root ganglion (DRG). Many BLT1expressing neurons are small in size and positive for TRPV1. BLT1-expressing fibers are present in the skin and results suggest the expression of functional BLT1 receptors in sensory neurons (Andoh and Kuraishi, 2005). Additionally, a correlation of nocturnal itch with high urinary leukotriene $\mathrm{E}_{4}$ levels was demonstrated, suggesting that increased production of leukotrienes may contribute to induction of nocturnal itch in AD (Miyoshi et al., 1999). Preliminary studies demonstrated reduction of pruritus in $A D$ patients during treatment with the leukotriene receptor antagonists zafirlukast and zileuton, a 5-lipoxygenase inhibitor (Carucci et al., 1998; Woodmansee and Simon, 1999). Other metabolites of arachidonic acid such as prostaglandin E2 and E1 may be involved in the pathogenesis of $A D$. Prostaglandin E2 evoked pruritus in $A D$ patients (Neisius et al., 2002) and prostaglandin E1 significantly lowered itch threshold (Lovell et al., 1976). Thromboxane A2 also has recently been reported to induce itch-associated scratching (Andoh et al., 2007).

Our results showed that 12(S)-hydroperoxyeicosa$5 Z, 8 Z, 10 E, 14 Z$-tetraenoic acid (12(S)-HPETE) induces a scratching response in mice (Kim et al., 2007). Involve- ment of BLT2 was demonstrated in the 12(S)-HPETE-induced scratching response using highly a selective BLT2 agonist such as compound A (Kim et al., 2008b). Recently, Ocuno reported that 12 (S)-hydroxyheptadeca-5Z, 8E, 10Etrienoic acid is a natural ligand for leukotriene $B_{4}$ receptor 2 (Okuno et al., 2008), and we expect this lipid also induces itch-scratch-response in mice via the BLT2 pathway.

Lysophosphatidic acid (LPA) is the simplest phospholipid, being composed of a phosphate, a glycerol and a fatty acid in its structure (Tigyi and Parrill, 2003). Lysophosphatidic acid is reported to induce a scratching response in mice and release of histamine in mast cells. These effects may be mediated by LPA receptors (Hashimoto et al., 2004; Hashimoto et al., 2005).

Recently, many studies have suggested that sphingolipids, especially sphingosine 1-phosphate, are involved in the pathophysiology of mast cells (Price et al., 2008; Ryu et al., 2009). We speculated that lipid byproducts from abnormal skin barrier disruption, such as SPC, might induce the symptoms of atopic dermatitis. Thus we tested whether sphingosylphosphorylcholine induces scratching response. We found that SPC dose-dependently induces scratching response in mice and these responses were specific for D-erythro-form SPC (Kim et al., 2008c; Kim et al., 2009). Andoh et al. reported that $\mathrm{LTB}_{4}$ from keratinocytes mediates sphingosylphosphorylcholine-induced itch-associated responses in mouse skin (Andoh et al., 2009). In addition, SPC evokes the degranulation of mast cells and increases the migration of mast cells into SPC-injected sites (Kim et al., 2010). These results suggested the possibility that SPC is not just a byproduct of abnormal skin barrier disruption, but could be a key factor for induction or aggravation of $A D$ symptoms, such as pruritus and inflammation (Imokawa et al., 1999; Kim et al., 2008c). It has recently been demonstrated that SPC down-regulates filaggrin gene transcription through NOX5-based NADPH oxidase and cyclooxygenase- 2 in human keratinocytes (Choi et al., 2010). These findings also support our view that SPC, a byproduct of abnormal skin barrier disruption, can play an active role in pathophysiology of atopic dermatitis.

\section{Histamine, and serotonin, proteinases and proteinase-activated receptors (Table II)}

Histamine is the most famous and well-studied pruritogen. Approximately 80 years ago, it was reported that intramuscular histamine injections resulted in pruritus, suggesting an important role of histamine in the pathogenesis of itching (Stander and Steinhoff, 2002). It was reported that pruritus, induced by the mast cell degranulating compound $48 / 80$ in AD patients, could not be relieved by cetir- 
Table II. Nociception in atopic skin: mediators and their mechanisms inducing pruritus in AD (for references see text)

\begin{tabular}{|c|c|c|c|}
\hline Mediator or receptor & Induction of itch & Mechanism & References \\
\hline Hista & $(+)$ & Direct binding to itch receptor & (Stander and Steinhoff, 2002) \\
\hline Serotonin & + & Serotonin receptor $5-\mathrm{HT}_{1}, 5-\mathrm{H}^{-}$ & $\begin{array}{l}\text { (Kim et al., 2008a; Weisshaar et al., 1997; } \\
\text { Yamaguchi et al., 1999) }\end{array}$ \\
\hline $\begin{array}{l}\text { TFLLR-NH }{ }_{2}(\mathrm{PAR}-1) \\
\text { AYPGKF-NH } \\
\text { (PAR-4) }\end{array}$ & + & Histamine dependent & (Tsujii et al., 2008) \\
\hline SLIGRL-NH 2 (PAR-2) & + & Histamine independent & (Shimada et al., 2006) \\
\hline oline & + & Not known & (Stander and Steinhoff, 2002) \\
\hline $\begin{array}{l}\text { Substance P (SP) } \\
\text { Arg-Pro-Lys-Pro-GIn-GIn- } \\
\text { Phe-Phe-Gly-Leu-Met }\end{array}$ & + & Histamine liberator & (Weidner et al., 2000) \\
\hline Gastrin-releasing peptides & + & GRPR & (Sun et al., 2009) \\
\hline Morphine & + & Opioid receptor & (Yokoyama et al., 2009) \\
\hline
\end{tabular}

izine $\mathrm{H} 1$ blocker (Rukwied et al., 2000). The lack of efficacy of currently used antihistamine medicines targeting $\mathrm{H} 1$ and $\mathrm{H} 2$ receptors in $\mathrm{AD}$ has led to the hypothesis that mast cell mediators, other than histamine, are the cause of these conditions, or that other types of histamine receptors exist (Rukwied et al., 2000; Badertscher et al., 2005).

The histamine $\mathrm{H} 4$ receptor is a newly discovered histamine receptor, expressed on hematopoietic cells, and is linked to the pathology of allergy and asthma (Yamaura et al., 2009). Histamine and a selective histamine $\mathrm{H} 4$ receptor agonist caused scratching responses in mice, which were almost completely attenuated in histamine $\mathrm{H} 4$ receptor knockout mice, or by pretreatment with the selective histamine H4 receptor antagonist, JNJ 7777120 (1). Pruritus induced by allergic mechanisms was also potently inhibited by treatment with histamine $\mathrm{H} 4$ receptor antagonist and in histamine $\mathrm{H} 4$ receptor knockout mice. In all cases, the inhibitory effect of a histamine $\mathrm{H} 4$ receptor antagonist was greater than that observed using histamine $\mathrm{H} 1$ receptor antagonists. The histamine $\mathrm{H} 4$ receptor-mediated pruritus was shown to be independent of mast cells or other hematopoietic cells and may result from actions on pe- ripheral neurons (Dunford et al., 2007). Recently, it has been shown that polymorphism of the $\mathrm{H} 4$ receptor is associated with $A D$ (Yu et al., 2010).

Serotonin (5-HT) seems to be an important endogenous mediator of acute itch. It produces a sensation of itch when applied to the human skin (Weisshaar et al., 1997) and has been suggested to be involved in the pruritus of polycythemia vera (Fjellner and Hagermark, 1979; Fitzsimons et al., 1981) and cholestasis (Schworer and Ramadori, 1995; Jones and Bergasa, 2000). We found that WAY100635 (3) and ketanserine (4) suppressed the 12(S)-HPETE-induced scratching in mice (Kim et al., 2008a). These results suggested that serotonin receptor 1 (5-HT1) and serotonin receptor 2 (5-HT2) are involved in 12(S)-HPETE-induced scratching response.

Paroxetine (2), a selective serotonin reuptake inhibitor (SSRI), was shown to have antipruritic activity in the $\mathrm{NC} /$ NGA mouse, an animal model for human AD. The mechanism for the antipruritic effect of paroxetine (2) remains unclear, but it was suggested that antipruritic effects of paroxetine (2) might be mediated through the same pathway as the serotonin receptor, especially the $5-\mathrm{HT} 3$ subtype (Jiang 
et al., 2007).

A role for proteinases, such as trypsin, papain and chymotrypsin as mediators of pruritus has been suggested for over 40 years (Stander and Steinhoff, 2002). Tryptase may be a key factor effecting itch responses in $A D$ patients. One important pathway for tryptase's action in itch responses may be the activation of proteinase-activated receptors (PAR) by tryptase. It was reported that tryptase binds to proteinase-activated receptor-2 (PAR-2) (Steinhoff et al., 2000). The endogenous PAR-2 agonist tryptase was increased up to fourfold in atopic dermatitis (AD) patients and PAR-2 was markedly enhanced on primary afferent nerve fibers in skin biopsies of AD patients (Steinhoff et al., 2003). Tryptase activates PAR-2 on skin cells such as keratinocytes and sensory nerves, thereby mediating inflammatory effects of mast cells. Intradermal injections of SLIGRL-NH2 (10-50 $\mu$ g), a well-known PAR-2 agonist, evoked dose-dependent scratching.

Many studies have been conducted concerning the relationship between PAR-mediated and histamine-related itching pathways. Activating peptides for PAR-1, PAR-2, and PAR-4, but not PAR-3, induced scratching. The antihistamine, terfenadine, suppressed scratching elicited by activating peptides for PAR-1 and PAR-4, but not PAR-2 (Shimada et al., 2006). Pretreatment of animals with a histamine $\mathrm{H} 1$ receptor antagonist, pyrilamine, suppressed histamine-induced scratching, but had little effect on SLIGRL scratching. These results suggest that PAR-1, PAR-2, and PAR-4 are involved in itch and that histamine is a cause of itch related to PAR-1 and PAR-4, but not PAR-2 (Tsujii et al., 2008). Thus PAR-2 mediates histamine independent itch (Shimada et al., 2006).

\section{Neurotransmitter, neuropeptides and opioid peptides (Table II)}

Acethylcholine (Ach) is believed to play a major role in eliciting itch sensations in patients with $A D$ and is a transmitter of the postganglionic sympathetic nervous system innervating eccrine sweat glands (Stander and Steinhoff, 2002). Interestingly, increased Ach levels, as found in lesional skin of patients with $A D$, suggest that increased production or release of Ach is implicated in the pathophysiology of pruritus in AD (Stander and Steinhoff, 2002). Furthermore, intradermal application of Ach resulted in pruritus, instead of pain, in patients suffering from AD (Heyer and Hornstein, 1999). Ach is also an important neurotransmitter for activating sweat glands, which may explain itching during and after sweating in patients suffering from AD (Stander and Steinhoff, 2002). Botulinum toxin type A reduces histamine-induced itch and vasomotor responses in human skin and is believed to be effective against itch, as it inhibits the release of acetylcholine (Gazerani et al., 2009).

Neuropeptides are relatively small peptides utilized by neurons to communicate with adjacent cells or neurons. At present, more than 100 different peptides are known to be released by different neurons (Zhang et al., 2010). Several reports support the idea that neuropeptides are involved in the pathophysiology of itching in AD (Slominski and Wortsman, 2000). It is well known that neuropeptides such as substance $P$ (Sub $P$ ), somatostatin, and neurotensin induce itch. Sub $P$ induces itch responses in humans by affecting the action of histamine from mast cells (Weidner et al., 2000). Alterations in the neuropeptide profile of nerve fibers were observed in patients of $A D$. The number of neuropeptide $\mathrm{Y}$-positive nerve fibres and Sub $\mathrm{P}$ concentrations were increased in AD patients (Schmelz, 2001). Stander and Steinhoff suggested that an imbalance of the cutaneous nervous system may be an important factor in the pathophysiology of pruritus in AD (Stander and Steinhoff, 2002). Significantly, the recent work by Sun and Chen, published in the journal Nature, reported the existence of an itch-specific, gastrin-releasing peptide (GRP)/gastrinreleasing peptide receptor (GRPR) mediated signaling pathway located within the dorsal horn of the spinal cord in mice (Sun and Chen, 2007; Swain, 2008). GRP is a specific itch-signaling molecule within the spinal cord. GRP is a bombesin-like peptide with high affinity for the bombesin type 2 receptor, GRPR.

Opioids have been reported to play a role in itch induced not only by histamine release from dermal mast cells, but also through direct central and peripheral pruritogenic effects, in addition to their major well-known role in pain (Stander and Steinhoff, 2002). Paraspinal application of opioid analgesics frequently induces itching, and opioid receptor antagonists have an inhibitory effect on pruritus (Stander and Steinhoff, 2002). The oral opioid receptor antagonist, naltrexone, is more efficient at blocking histamine-induced itch than the antihistamine, cetirizine (5) (Heyer and Hornstein, 1999) in patients with AD. Itch scratching responses induced by 12(S)-HPETE and SPC also were blocked by naltrexone (Kim et al., 2007; Kim et al., 2008b; Kim et al., 2008c). These results suggested that opioid receptors might be located within the dorsal horn of the spinal cord in mice, but it is also possible that opioid receptors, located in peripheral nerve ending, interact with BLT2 or a hypothetical SPC receptor (not yet identified). 
ANTIPRURITIC THERAPY AND NEW TARGETS OF ITCHING IN ATOPIC DERMATITIS

There are many reviews covering the therapy of pruritus in diverse diseases, although existing therapies do not satisfactorily fulfill the medical needs (Summey and Yosipo- vitch, 2005; Greaves, 2007; Lynde et al., 2008). FolsterHolst and Christophers reported the various therapeutic methods for controlling the pruritus of $A D$ (Folster-Holst and Christophers, 2001). In the next section, I will briefly describe the current therapies for controlling the pruritus in $A D$ and provide updates on new therapies and emerging

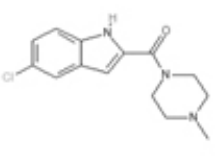

JNJ 7777120 (1)

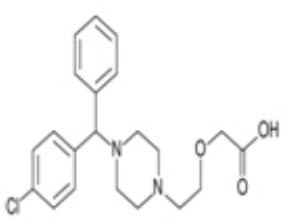

Cetirizine (5)

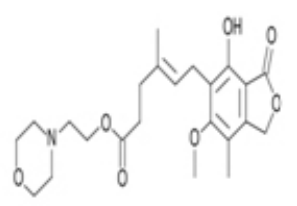

Mycophenolate (9)

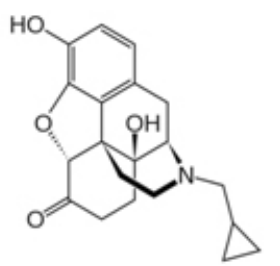

Naltrexone (13)<smiles>Fc1ccc(C2CCNCC2COc2ccc3c(c2)OCO3)cc1</smiles>

Paroxetine (2)

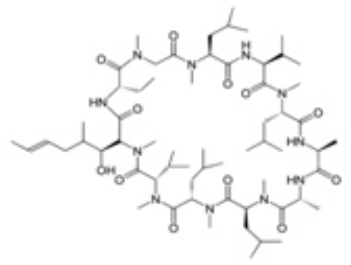

Cyclosporine A (6)<smiles>CN(C)CC/C=C1\c2ccccc2COc2ccccc21</smiles>

Doxepin (10)<smiles>Oc1ccc2c(c1)C13CCCCC1(CCN(CC1CCC1)C2)C3O</smiles>

Butorphanol (14)<smiles>COc1ccccc1N1CCN(CCN(C(=O)C2CCCCC2)c2ccccn2)CC1</smiles>

WAY100635(3)

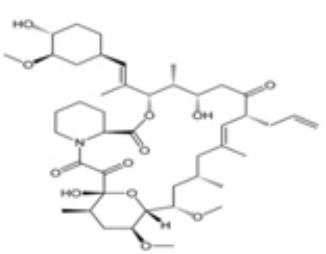

FK506 (7)<smiles>CC(C)[C@H]1CC[C@@H](C)C[C@H]1O</smiles>

Menthol(11)<smiles>CCCCC(CN)(CCCC)CC(=O)O</smiles>

Gabapentin (15)<smiles>O=C(c1ccc(F)cc1)C1CCN(CCn2c(=O)[nH]c3ccccc3c2=O)CC1</smiles>

Ketanserine (4)

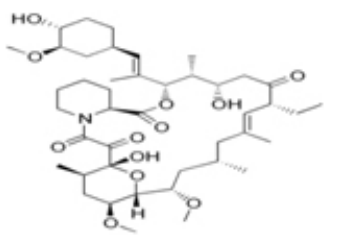

Ascomycines (8)<smiles>COc1cc(CNC(O)CCCC/C=C/C(C)C)ccc1O</smiles>

Capsaicin (12)

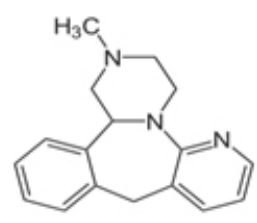

Mirtazepine (17)<smiles>O=C1CC[C@H](N2C(=O)c3ccccc3C2=O)C(=O)N1</smiles>

Thalidomide (18)<smiles>CCN(CC)CCCC(C)Nc1ccnc2cc(Cl)ccc12</smiles>

Chloroquine (19)

Fig. 1. Structures of antipruritic compounds. 
targets for controlling pruritus.

\section{Antipruritic therapy in atopic dermatitis (Fig. 1)}

So far, most effective and consistent antipruritics are systemic immunomodulators, such as cyclosporine A (6), FK506 (7), ascomycines (8), mycophenolate mofetil (9), INF- $\gamma$ and ultraviolet light therapy. The decreased itch intensity may result from reduction of inflammatory cells and alleviation of itch by direct action on nerve fibers (Yosipovitch et al., 1996). However, serious side-effects can result upon long-term application of immunomodulators, necessitating development of new approaches in antipruritic therapy.

Antihistamines are usually not effective unless the pruritus is primarily mediated by histamine, e.g., urticaria, although the sedative action of the first-generation $\mathrm{H} 1$ antihistamines may be useful in other cases of chronic pruritus (Greaves, 2007). Recently, it has been demonstared that the histamine $\mathrm{H} 4$ receptor (H4R) mediates inflammation and pruritus in Th2-dependent dermal inflammation, such as atopic dermatitis. Therefore, the H4R antagonist, JNJ 7777120 (1) also significantly inhibited the pruritus in a mouse skin inflammation model (Cowden et al., 2010).

Oral doxepin (10), a tricyclic compound, is a powerful antipruritic, retaining greater potency as an $\mathrm{H} 1$ antihistamine than any other available $\mathrm{H} 1$ antagonist (Figueiredo et al., 1990). Doxepin 5\% cream also reduces pruritic symptoms of atopic dermatitis. Patients treated with doxepin should be cautioned regarding adverse side-effects, such as systemic absorption and drowsiness. It should be used carefully in patients with liver or cardiovascular disease (Greaves, 2007). Long term use of doxepin induced contact allergies (Shelley et al., 1996).
Menthol (11) $1 \%$, formulated in an aqueous cream or in a moisturizer base, sensitizes thermal receptors to cold and is considered a safe remedy that has been used for centuries. Capsaicin (12) $0.025-0.3 \%$ cream is derived from chili peppers, and induces the release of Sub P from C nociceptors via vanilloid receptor (TRPV1), which desensitizes nerve fibers, however, local irritation by capsaicin (12) can limit the use of this drug.

Opioid antagonists, including oral naltrexone (13), are effective for a variety of other pruritic disorders (Metze et al., 1999). Naltrexone (13), showed to be significantly more effective than placebo in the treatment of pruritus in patients with chronic eczema and decreasing visual analogue scale scores after 1 week $(p<0.005)$ and 2 weeks ( $p$ $<0.001$ ) (Malekzad et al., 2009). Butorphanol (14), a dual $\mu$-receptor antagonist and $\kappa$-receptor agonist, applied as a nasal spray, has demonstrated remarkable promise for treating intractable pruritus (Dawn and Yosipovitch, 2006). Butorphanol, $2 \mathrm{mg} /$ day, was effective in preventing pruritus associated with continuous epidural infusion of morphine, $3.3 \mathrm{mg} /$ day (Yokoyama et al., 2009), however, the application of butorphanol in AD is not yet reported.

Gabapentin (15), a structural analogue of $\gamma$-amino butyric acid and an anticonvulsant, has been reported as a potent antipruritic in one double blind placebo-controlled trial in haemodialysis patients (Gunal et al., 2004). Gabapentin has been reported to be administered systematically in skin diseases (Ballmer-Weber and Dummer, 2007).

Leukotrienes are mainly produced by mast cells, and contribute to the local inflammation and development of pruritus. Two small studies suggested efficacy of a leukotriene antagonist or 5-lipoxygenase inhibitor in treatment of AD patients (Capella et al., 2001; Taskapan, 2001), and

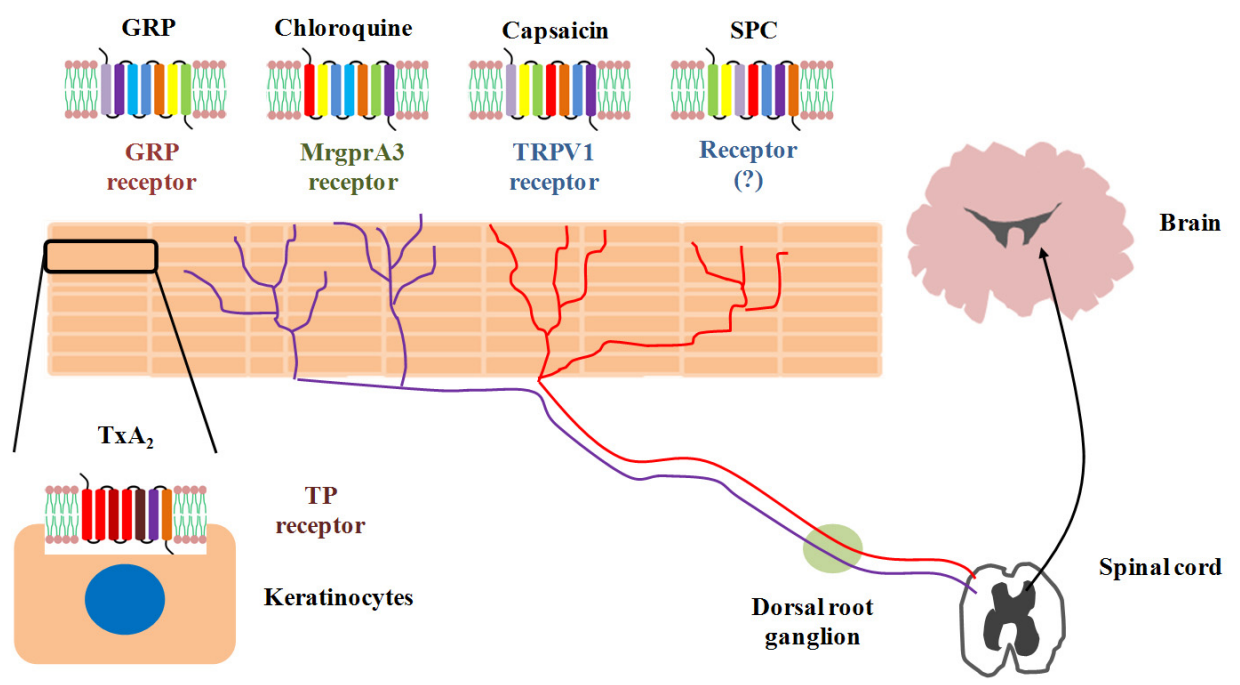

Fig. 2. New emerging targets for antipruritic control. This figure oversimplifies locations and structures of targets. Please see the references for detailed informations. 
montelukast (16) also reduces itching, sleep disturbance, blood eosinophil count and serum IgE in children with $A D$. However, larger controlled prospective studies are needed to confirm these findings.

There is also evidence that type 4 phosphodiesterase inhibitors have anti-inflammatory and antipruritic activities in patients with $A D$ (Hanifin et al., 1996). Other drugs that can be used in controlling of pruritus of $A D$ include mirtazepine (17), a 5-HT3 receptor antagonist (Davis et al., 2003), paroxetine (2), (Zylicz et al., 2003) and thalidomide (18) (Daly and Shuster, 2000).

\section{New emerging targets and the chances of new antipruritics (Fig. 2)}

Induction of scratching behaviour in response to pruritogenic stimuli was significantly reduced in GRPR mutant mice, whereas normal responses were evoked by painful stimuli. Moreover, direct spinal cerebrospinal fluid injection of a GRPR antagonist significantly inhibited scratching behaviour in three independent itch models (Sun and Chen, 2007; Sun et al., 2009). GRPR ${ }^{+}$neurons constitute a longsought labeled line for itch sensation in the spinal cord (Sun et al., 2009). The pharmacological effects of GRPR antagonists have been studied in many cancers (de Oliveira et al., 2009; Sotomayor et al., 2010). These GRPR antagonists are expected to be useful in controlling the pruritus of AD.

Itch induced by chloroquine (CQ; 18$)$ is a common side effect of this widely used antimalarial drug. Mrgprs, a family of $\mathrm{G}$ protein-coupled receptors expressed exclusively in peripheral sensory neurons, function as itch receptors. Mice lacking a cluster of Mrgpr genes display significant deficits in itch induced by $C Q$ (18) but not by histamine. CQ (18) directly excites sensory neurons in a Mrgpr-dependent manner and specifically activates mouse MrgprA3 and human MrgprX1. Loss- and gain-of-function studies demonstrate that MrgprA3 is required for $C Q$ (18) responsiveness in mice. Furthermore, MrgprA3-expressing neurons respond to histamine and coexpress gastrin- releasing peptide, a peptide involved in itch sensation, and MrgprC11 (Liu et al., 2009).

Several lines of novel evidence suggest the involvement of new players in the process of itch (Biro et al., 2007). Special attention has centered on the transient receptor potential (TRP) superfamily, especially to the thermosensitive members (Dhaka et al., 2006). The generally accepted basis for therapeutic application of capsaicin (12) to control itch is the well-accepted desensitizing effect of this vanilloid (Biro et al., 2007). The fact that itch pathway is clearly sensitive to temperature changes indicates the involve- ment of TRP channels. Recently, it is reported that patients with allergic rhinitis may be abnormally sensitive to stimulation of the ion channel transient receptor potential vanilloid-1 (TRPV1) and that TRPV1-activators also induce itch (Alenmyr et al., 2009). Kim et al. already reported that histamine activates TRPV1 after stimulating the phospholipase A2/lipoxygenase pathway, leading to the excitation of sensory neurons, and described the potential use of TRPV1 antagonists as anti-itch drugs (Kim et al., 2004). Therefore TRPV1 antagonists are expected to be novel candidates for suppressing itch of atopic dermatitis.

Sphingosylphosphorylcholine (SPC), which is one of breakdown products of abnormal skin barrier in $A D$ patients, induced itch-associated scratch response in mice (Kim et al., 2008c). SPC also induced the degranulation of mast cells (Kim et al., 2009). From the fact that these actions of SPC are stereospecific, I can expect the existence of a specific receptor. These results suggested that modulation of SPC action and elucidation of the SPC target might help to modulate the pruritus of atopic dermatitis.

Recently, Japanese groups have investigated the role of keratinocytes in the itch circuit (Andoh, 2008). They demonstrated that thromboxane A2 induces itch-scratching response through thromboxane $\mathrm{A} 2$ receptor (TP) receptors in the skin in mice (Andoh et al., 2007). These results suggested that interaction between keratinocytes and sensory nerves is involved in itch response and diverse receptors and targets on keratinocytes might be candidates for controlling the itch of atopic dermatitis. These views might be supported by the existence of targets, such as TRPV1 and TP receptors, on keratinocytes (Peier et al., 2002; Li et al., 2007; Andoh, 2008).

\section{SUMMARY AND FUTURE DIRECTIONS}

There are no single, easily applicable, well-tolerated, and universally effective pharmacological anti-itch drugs for AD (Biro et al., 2007). Thus, controlling of itch is one of key unmet needs in patients suffering from $A D$. Recent progress has revealed that besides histamine, several mediators (pruritogens) such as neuropeptides, neurotransmitters, proteinases and arachidonic derivates, such as leukotrienes and prostaglandins, appear to play important roles for the induction of pruritus during $A D$. Identifying new pruritogens and related new targets mediating the itch-scratching responses might help us to develop new antipruritics for modulating the pruritus of atopic dermatitis. 


\section{ACKNOWLEDGMENTS}

This work was supported by a Research Program for New Drug Target Discovery grant (2009-0083364) from the Ministry of Education, Science \& Technology, Korea.

\section{REFERENCES}

Abeck, D., Andersson, T., Grosshans, E., Jablonska, S., Kragballe, K., Vahlquist, A., Schmidt, T., Dupuy, P. and Ring, J. (1997). Topical application of a platelet-activating factor (PAF) antagonist in atopic dermatitis. Acta. Derm. Venereol. 77, 449-451.

Alenmyr, L., Hogestatt, E. D., Zygmunt, P. M. and Greiff, L. (2009). TRPV1-mediated itch in seasonal allergic rhinitis. Allergy 64, 807-810.

Andoh, T. (2008). Mechanisms of cutaneous itch: new itch mediators and enhancement factors produced by keratinocytes. Nippon Yakurigaku Zasshi 131, 361-366.

Andoh, T. and Kuraishi, Y. (1998). Intradermal leukotriene B4, but not prostaglandin E2, induces itch-associated responses in mice. Eur. J. Pharmacol. 353, 93-96.

Andoh, T. and Kuraishi, Y. (2005). Expression of BLT1 leukotriene $B 4$ receptor on the dorsal root ganglion neurons in mice. Brain Res. Mol. Brain Res. 137, 263-266.

Andoh, T., Nishikawa, Y., Yamaguchi-Miyamoto, T., Nojima, H., Narumiya, S. and Kuraishi, Y. (2007). Thromboxane A2 induces itch-associated responses through TP receptors in the skin in mice. J. Invest Dermatol. 127, 2042-2047.

Andoh, T., Saito, A. and Kuraishi, Y. (2009). Leukotriene B(4) mediates sphingosylphosphorylcholine-induced itch-associated responses in mouse skin. J. Invest. Dermatol. 129, 2854 2860

Badertscher, K., Bronnimann, M., Karlen, S., Braathen, L. R. and Yawalkar, N. (2005). Mast cell chymase is increased in chronic atopic dermatitis but not in psoriasis. Arch. Dermatol. Res. 296, 503-506.

Ballmer-Weber, B. K. and Dummer, R. (2007). Pruritus in frequent skin diseases and therapeutic options. Praxis (Bern 1994) 96, 107-111.

Biro, T., Toth, B. I., Marincsak, R., Dobrosi, N., Geczy, T. and Paus, R. (2007). TRP channels as novel players in the pathogenesis and therapy of itch. Biochim. Biophys. Acta. 1772, 1004-1021.

Capella, G. L., Grigerio, E. and Altomare, G. (2001). A randomized trial of leukotriene receptor antagonist montelukast in moderate-to-severe atopic dermatitis of adults. Eur. J. Dermatol. 11, 209-213.

Carucci, J. A., Washenik, K., Weinstein, A., Shupack, J. and Cohen, D. E. (1998). The leukotriene antagonist zafirlukast as a therapeutic agent for atopic dermatitis. Arch. Dermatol. 134, 785-786

Choi, H., Kim, S., Kim, H. J., Kim, K. M., Lee, C. H., Shin, J. H. and Noh, M. (2010). Sphingosylphosphorylcholine downregulates filaggrin gene transcription through NOX5-based $\mathrm{NADPH}$ oxidase and cyclooxygenase- 2 in human keratinocytes. Biochem. Pharmacol. 80, 95-103.
Cowden, J. M., Zhang, M., Dunford, P. J. and Thurmond, R. L. (2010). The histamine $\mathrm{H} 4$ receptor mediates inflammation and pruritus in Th2-dependent dermal inflammation. $J$. Invest. Dermatol. 130, 1023-1033.

Czarnetzki, B. M. and Csato, M. (1989). Comparative studies of human eosinophil migration towards platelet-activating factor and leukotriene B4. Int. Arch. Allergy Appl. Immunol. 88, 191-193.

Daly, B. M. and Shuster, S. (2000). Antipruritic action of thalidomide. Acta. Derm. Venereol. 80, 24-25

Davis, M. P., Frandsen, J. L., Walsh, D., Andresen, S. and Taylor, S. (2003). Mirtazapine for pruritus. J. Pain Symptom. Manage 25, 288-291.

Dawn, A. G. and Yosipovitch, G. (2006). Butorphanol for treatment of intractable pruritus. J. Am. Acad. Dermatol. 54, 527-531.

de Oliveira, M. S., Cechim, G., Braganhol, E., Santos, D. G. Meurer, L., de Castro, C. G. Jr., Brunetto, A. L., Schwartsmann, G., Battastini, A. M., Lenz, G. and Roesler, R. (2009). Anti-proliferative effect of the gastrin-release peptide receptor antagonist RC-3095 plus temozolomide in experimental glioblastoma models. J. Neurooncol. 93, 191-201.

Dhaka, A., Viswanath, V. and Patapoutian, A. (2006). Trp ion channels and temperature sensation. Annu. Rev. Neurosci. 29, 135-161.

Dunford, P. J., Williams, K. N., Desai, P. J., Karlsson, L., McQueen, D. and Thurmond, R. L. (2007). Histamine H4 receptor antagonists are superior to traditional antihistamines in the attenuation of experimental pruritus. J. Allergy Clin. Immunol. 119, 176-183.

Ellis, C. N., Drake, L. A., Prendergast, M. M., Abramovits, W., Boguniewicz, M., Daniel, C. R., Lebwohl, M., Stevens, S. R., Whitaker-Worth, D. L., Cheng, J. W. and Tong, K. B. (2002). Cost of atopic dermatitis and eczema in the United States. $J$. Am. Acad. Dermatol. 46, 361-370.

Figueiredo, A., Ribeiro, C. A., Goncalo, M., Almeida, L., PoiaresBaptista, A. and Teixeira, F. (1990). Mechanism of action of doxepin in the treatment of chronic urticaria. Fundam. Clin. Pharmacol. 4, 147-158.

Fitzsimons, E. J., Dagg, J. H. and McAllister, E. J. (1981) Pruritus of polycythaemia vera: a place for pizotifen? Br. Med. J. (Clin Res Ed) 283, 277.

Fjellner, B. and Hagermark, O. (1979). Pruritus in polycythemia vera: treatment with aspirin and possibility of platelet involvement. Acta. Derm. Venereol. 59, 505-512.

Fjellner, B. and Hagermark, O. (1985). Experimental pruritus evoked by platelet activating factor (PAF-acether) in human skin. Acta. Derm. Venereol. 65, 409-412.

Folster-Holst, R. and Christophers, E. (2001). Antipruritic therapy in atopic eczema. Hautarzt. 52, 853-861.

Gazerani, P., Pedersen, N. S., Drewes, A. M. and ArendtNielsen, L. (2009). Botulinum toxin type A reduces histamineinduced itch and vasomotor responses in human skin. Br. J. Dermatol. 161, 737-745.

Greaves, M. W. (2007). Recent advances in pathophysiology and current management of itch. Ann. Acad. Med. Singapore 36, 788-792.

Gunal, A. I., Ozalp, G., Yoldas, T. K., Gunal, S. Y., Kirciman, E. and Celiker, H. (2004). Gabapentin therapy for pruritus in haemodialysis patients: a randomized, placebo-controlled, 
double-blind trial. Nephrol. Dial. Transplant 19, 3137-3139.

Hanifin, J. M., Chan, S. C., Cheng, J. B., Tofte, S. J., Henderson, W. R. Jr., Kirby, D. S. and Weiner, E. S. (1996). Type 4 phosphodiesterase inhibitors have clinical and in vitro anti-inflammatory effects in atopic dermatitis. J. Invest. Dermatol. 107, 51-56.

Hashimoto, T., Ohata, H. and Momose, K. (2004). Itch-scratch responses induced by lysophosphatidic acid in mice. Pharmacology 72, 51-56.

Hashimoto, T., Ohata, H., Momose, K. and Honda, K. (2005). Lysophosphatidic acid induces histamine release from mast cells and skin fragments. Pharmacology 75, 13-20.

Heyer, G. R. and Hornstein, O. P. (1999). Recent studies of cutaneous nociception in atopic and non-atopic subjects. $J$. Dermatol. 26, 77-86.

Imokawa, G., Takagi, Y., Higuchi, K., Kondo, H. and Yada, Y. (1999). Sphingosylphosphorylcholine is a potent inducer of intercellular adhesion molecule-1 expression in human keratinocytes. J. Invest. Dermatol. 112, 91-96.

Jiang, J., Kuhara, T., Ueki, R., Zheng, Y., Suto, H., Ikeda, S. and Ogawa, H. (2007). Inhibitory effects of paroxetine on the development of atopic dermatitis-like lesions in $\mathrm{NC} / \mathrm{Nga}$ mice. J. Dermatol. Sci. 47, 244-247.

Jones, E. A. and Bergasa, N. V. (2000). Evolving concepts of the pathogenesis and treatment of the pruritus of cholestasis. Can. J. Gastroenterol. 14, 33-40.

Kim, B. M., Lee, S. H., Shim, W. S. and Oh, U. (2004). Histamineinduced $\mathrm{Ca}(2+)$ influx via the PLA(2)/lipoxygenase/TRPV1 pathway in rat sensory neurons. Neurosci. Lett. 361, 159-162.

Kim, D. K., Kim, H. J., Kim, H., Koh, J. Y., Kim, K. M., Noh, M. S., Kim, J. J. and Lee, C. H. (2008a). Involvement of serotonin receptors 5 -HT1 and 5-HT2 in 12(S)-HPETEinduced scratching in mice. Eur. J. Pharmacol. 579, 390394.

Kim, D. K., Kim, H. J., Sung, K. S., Kim, H., Cho, S. A., Kim, K. M., Lee, C. H. and Kim, J. J. (2007). 12(S)-HPETE induces itch-associated scratchings in mice. Eur. J. Pharmacol. 554 30-33.

Kim, H. J., Kim, D. K., Kim, H., Koh, J. Y., Kim, K. M., Noh, M. S., Lee, S., Kim, S., Park, S. H., Kim, J. J., Kim, S. Y. and Lee, C. H. (2008b). Involvement of the BLT2 receptor in the itch-associated scratching induced by 12-(S)-lipoxygenase products in ICR mice. Br. J. Pharmacol. 154, 1073-1078.

Kim, H. J., Kim, H., Han, E. S., Park, S. M., Koh, J. Y., Kim, K. M., Noh, M. S., Kim, J. J. and Lee, C. H. (2008c). Characterizations of sphingosylphosphorylcholine-induced scratching responses in ICR mice using naltrexon, capsaicin, ketotifen and Y-27632. Eur. J. Pharmacol. 583, 92-96

Kim, H. J., Kim, K. M., Koh, J. Y., Noh, M. S., Park, M. K., Lee, H. J., Kim, S. Y. and Lee, C. H. (2010). Sphingosylphosphorylcholine induces degranulation of mast cells in the skin and plasma exudation in the ears of mice. J. Dermatol. Sci. 57, 57-59.

Leung, D. Y. and Soter, N. A. (2001). Cellular and immunologic mechanisms in atopic dermatitis. J. Am. Acad. Dermatol. 44, S1-S12.

Lewis-Jones, S. (2005). Measuring the burden of atopic eczema in young children and the family unit. J. Invest. Dermatol. 125, viii.
Li, W. H., Lee, Y. M., Kim, J. Y., Kang, S., Kim, S., Kim, K. H., Park, C. H. and Chung, J. H. (2007). Transient receptor potential vanilloid-1 mediates heat-shock-induced matrix metalloproteinase-1 expression in human epidermal keratinocytes. J. Invest. Dermatol. 127, 2328-2335.

Liu, Q., Tang, Z., Surdenikova, L., Kim, S., Patel, K. N., Kim, A., Ru, F., Guan, Y., Weng, H. J., Geng, Y., Undem, B. J., Kollarik, M., Chen, Z. F., Anderson, D. J. and Dong, X (2009). Sensory neuron-specific GPCR Mrgprs are itch receptors mediating chloroquine-induced pruritus. Cell 139, 1353-1365.

Lovell, C. R., Burton, P. A., Duncan, E. H. and Burton, J. L. (1976). Prostaglandins and pruritus. Br. J. Dermatol. 94, 273-275.

Lynde, C. B., Kraft, J. N. and Lynde, C. W. (2008). Novel agents for intractable itch. Skin Therapy Lett. 13, 6-9.

Malekzad, F., Arbabi, M., Mohtasham, N., Toosi, P., Jaberian, M., Mohajer, M., Mohammadi, M. R., Roodsari, M. R. and Nasiri, S. (2009). Efficacy of oral naltrexone on pruritus in atopic eczema: a double-blind, placebo-controlled study. J. Eur. Acad. Dermatol. Venereol. 23, 948-950.

Metze, D., Reimann, S., Beissert, S. and Luger, T. (1999). Efficacy and safety of naltrexone, an oral opiate receptor antagonist, in the treatment of pruritus in internal and dermatological diseases. J. Am. Acad. Dermatol. 41, 533539.

Miyoshi, M., Sakurai, T. and Kodama, S. (1999). Clinical evaluation of urinary leukotriene E4 levels in children with atopic dermatitis. Arerugi. 48, 1148-1152.

Neisius, U., Olsson, R., Rukwied, R., Lischetzki, G. and Schmelz, M. (2002). Prostaglandin E2 induces vasodilation and pruritus, but no protein extravasation in atopic dermatitis and controls. J. Am. Acad. Dermatol. 47, 28-32.

Okuno, T., lizuka, Y., Okazaki, H., Yokomizo, T., Taguchi, R. and Shimizu, T. (2008). 12(S)-Hydroxyheptadeca-5Z, 8E, $10 \mathrm{E}-$ trienoic acid is a natural ligand for leukotriene B4 receptor 2. J. Exp. Med. 205, 759-766.

Peier, A. M., Reeve, A. J., Andersson, D. A., Moqrich, A., Earley, T. J., Hergarden, A. C., Story, G. M., Colley, S., Hogenesch, J. B., Mclntyre, P., Bevan, S. and Patapoutian, A. (2002). A heat-sensitive TRP channel expressed in keratinocytes. Science 296, 2046-2049.

Price, M. M., Oskeritzian, C. A., Milstien, S. and Spiegel, S. (2008). Sphingosine-1-phosphate synthesis and functions in mast cells. Future Lipidol. 3, 665-674.

Rukwied, R., Lischetzki, G., McGlone, F., Heyer, G. and Schmelz, M. (2000). Mast cell mediators other than histamine induce pruritus in atopic dermatitis patients: a dermal microdialysis study. Br. J. Dermatol. 142, 1114-1120.

Ryu, S. D., Lee, H. S., Suk, H. Y., Park, C. S. and Choi, O. H. (2009). Cross-linking of FcepsilonRI causes $\mathrm{Ca}^{2+}$ mobilization via a sphingosine kinase pathway in a clathrindependent manner. Cell Calcium. 45, 99-108.

Schmelz, M. (2001). A neural pathway for itch. Nat. Neurosci. 4, 9-10.

Schworer, H. and Ramadori, G. (1995). Cholestatic pruritus-pathophysiology and therapy with special reference to treatment with 5-hydroxytryptamine subtype 3 receptor antagonists. Z. Gastroenterol. 33, 265-274.

Shelley, W. B., Shelley, E. D. and Talanin, N. Y. (1996). Self- 
potentiating allergic contact dermatitis caused by doxepin hydrochloride cream. J. Am. Acad. Dermatol. 34, 143-144.

Shimada, S. G., Shimada, K. A. and Collins, J. G. (2006). Scratching behavior in mice induced by the proteinaseactivated receptor-2 agonist, SLIGRL-NH2. Eur. J. Pharmacol. 530, 281-283.

Sotomayor, S., Munoz-Moreno, L., Carmena, M. J., Schally, A. V., Sanchez-Chapado, M., Prieto, J. C. and Bajo, A. M. (2010). Regulation of HER expression and transactivation in human prostate cancer cells by a targeted cytotoxic bombesin analog (AN-215) and a bombesin antagonist (RC3095). Int. J. Cancer. in press.

Stander, S. and Steinhoff, M. (2002). Pathophysiology of pruritus in atopic dermatitis: an overview. Exp. Dermatol. 11, 12-24.

Steinhoff, M., Neisius, U., Ikoma, A., Fartasch, M., Heyer, G., Skov, P. S., Luger, T. A. and Schmelz, M. (2003). Proteinaseactivated receptor-2 mediates itch: a novel pathway for pruritus in human skin. J. Neurosci. 23, 6176-6180.

Steinhoff, M., Vergnolle, N., Young, S. H., Tognetto, M., Amadesi, S., Ennes, H. S., Trevisani, M., Hollenberg, M. D., Wallace, J. L., Caughey, G. H., Mitchell, S. E., Williams, L. M., Geppetti, P., Mayer, E. A. and Bunnett, N. W. (2000). Agonists of proteinase-activated receptor 2 induce inflammation by a neurogenic mechanism. Nat. Med. 6, 151-158.

Summey, B. T., Jr. and Yosipovitch, G. (2005). Pharmacologic advances in the systemic treatment of itch. Dermatol. Ther. 18, 328-332.

Sun, Y. G. and Chen, Z. F. (2007). A gastrin-releasing peptide receptor mediates the itch sensation in the spinal cord. Nature 448, 700-703.

Sun, Y. G., Zhao, Z. Q., Meng, X. L., Yin, J., Liu, X. Y. and Chen, Z. F. (2009). Cellular basis of itch sensation. Science 325, $1531-1534$.

Swain, M. G. (2008). Gastrin-releasing peptide and pruritus: more than just scratching the surface. J. Hepatol. 48, 681683.

Taskapan, M. O. (2001). Zileuton and atopic dermatitis. Ann. Allergy Asthma. Immunol. 87, 162-163.

Tigyi, G. and Parrill, A. L. (2003). Molecular mechanisms of lysophosphatidic acid action. Prog. Lipid Res. 42, 498-526.

Tominaga, M., Ozawa, S., Ogawa, H. and Takamori, K. (2007). A hypothetical mechanism of intraepidermal neurite formation in NC/Nga mice with atopic dermatitis. J. Dermatol. Sci.
46, 199-210.

Tsujii, K., Andoh, T., Lee, J. B. and Kuraishi, Y. (2008). Activation of proteinase-activated receptors induces itch-associated response through histamine-dependent and -independent pathways in mice. J. Pharmacol. Sci. 108, 385-388.

Weidner, C., Klede, M., Rukwied, R., Lischetzki, G., Neisius, U., Skov, P. S., Petersen, L. J. and Schmelz, M. (2000). Acute effects of substance $P$ and calcitonin gene-related peptide in human skin-a microdialysis study. J. Invest. Dermatol. 115, 1015-1020.

Weisshaar, E., Ziethen, B. and Gollnick, H. (1997). Can a serotonin type 3 (5-HT3) receptor antagonist reduce experimentally-induced itch? Inflamm. Res. 46, 412-416.

Woodmansee, D. P. and Simon, R. A. (1999). A pilot study examining the role of zileuton in atopic dermatitis. Ann. Allergy Asthma. Immunol. 83, 548-552.

Yamaura, K., Oda, M., Suwa, E., Suzuki, M., Sato, H. and Ueno, K. (2009). Expression of histamine H4 receptor in human epidermal tissues and attenuation of experimental pruritus using $\mathrm{H} 4$ receptor antagonist. J. Toxicol. Sci. 34, 427-431.

Yokoyama, Y., Yokoyama, T., Nagao, Y., Nakagawa, T. and Magaribuchi, T. (2009). Treatment of epidural morphine induced pruritus with butorphanol. Masui. 58, 178-182.

Yosipovitch, G. and Papoiu, A. D. (2008). What causes itch in atopic dermatitis? Curr. Allergy. Asthma. Rep. 8, 306-311.

Yosipovitch, G., Szolar, C., Hui, X. Y. and Maibach, H. (1996). High-potency topical corticosteroid rapidly decreases histamine-induced itch but not thermal sensation and pain in human beings. J. Am. Acad. Dermatol. 35, 118-120.

Yu, B., Shao, Y., Zhang, J., Dong, X. L., Liu, W. L., Yang, H., Liu, L., Li, M. H., Yue, C. F., Fang, Z. Y., Zhang, C., Hu, X. P., Chen, B. C., Wu, Q., Chen, Y. W., Zhang, W. and Wan, J. (2010). Polymorphisms in human histamine receptor $\mathrm{H} 4$ gene are associated with atopic dermatitis. Br. J. Dermatol. 162, 1038-1043.

Zhang, X., Bao, L. and Ma, G. Q. (2010). Sorting of neuropeptides and neuropeptide receptors into secretory pathways. Prog. Neurobiol. 90, 276-283.

Zylicz, Z., Krajnik, M., Sorge, A. A. and Costantini, M. (2003). Paroxetine in the treatment of severe non-dermatological pruritus: a randomized, controlled trial. J. Pain. Symptom. Manage 26, 1105-1112. 